\title{
Macro Determinants of Foreign Direct Investment in Lebanon
}

\author{
Sarah Chehade ${ }^{1,2}$ \\ ${ }^{1}$ School of Business, Faculty of Finance and Accounting, Department of Accountancy and Financial \\ Management, Prague University of Economics and Business, Prague, Czech Republic \\ ${ }^{2}$ School of Business, Department of Accounting Information System (BAIS), Lebanese International University, \\ Lebanon \\ Correspondence: Sarah Chehade, University of Economics, Prague, Faculty of Finance and Accounting, \\ Department of Accountancy and Financial Management, W. Churchill Sq. 4, 13067 Prague 3, Czech Republic. \\ E-mail: ches06@vse.cz
}

Received: August 13, 2021

doi:10.5539/ass.v17n10p10
Accepted: September 1, 2021

Online Published: September 19, 2021

URL: https://doi.org/10.5539/ass.v17n10p10

\begin{abstract}
This paper is concerned with identifying and analysing the impact of selected macroeconomic variables on foreign direct investment (FDI) in Lebanon. Toward this purpose, the analysis will be based on secondary data collected for the period standing between 1990 and 2018 to implement the Vector Auto Regression (VAR) and Error correction model (ECM) techniques. The results reveal that Gross Domestic Product (GDP), deposit interest rate and debt are correlated with FDI. While trade was found statistically an insignificant variable for FDI inflow. The findings of the study recommend that establishing and maintaining economic stability and growth will spurs foreign investments in Lebanon.
\end{abstract}

Keywords: Debt, Error Correction Model (ECM), Foreign Direct Investment (FDI), Gross Domestic Product (GDP), Interest rate, Trade.

\section{Introduction}

Globalization had faced and still facing a huge expansion worldwide. Emerging economies in the search of growth and macroeconomic stability are taking part of this globalization and more precisely in the economic field in the form of Foreign Direct Investment (FDI) (Siddiqui \& Aumeboonsuke, 2014). Foreign direct investment is defined as an investment made by an entity in one country into the interest of another entity located in another country such as business mergers and acquisitions (Atal et al., 2016). FDI goes beyond capital investment to include the provision of management and technology. According to Erdal and Tatoglu (2002), due to the high rate of liberalization movements, developing economies have seen a remarkable increase in FDI inflow in the 1990s so that it reached around 40 per cent of the global FDI nowadays.

The Middle East and North Africa (MENA) region includes countries with heterogeneous economic structures. These countries are known for their share of common characteristics that may discourage investors from taking a step toward FDI. Some of these features include political and macroeconomic instability that led to investment risk from the investor's perspective, slow tempo of privatisation, the weak economic base due to high dependency on oil and gas, and underdeveloped financial and capital markets (Shirazi et al., 2008; Atal et al., 2016; Caccia et al., 2018). Although the ongoing constraints, MENA countries are aware of the need to shape its economic structure to a more investor-friendly economy by making some business restructuring. And the result was noted in the increased volume of FDI inflows to MENA countries during the last 10 years.

Lebanon as any other developing country located in the MENA region has experienced the FDI trend. Lebanon is said to have free economy with around 15 listed companies according to Beirut Stock Exchange. According to Central Bank of Lebanon, the story of FDI in Lebanon had started in early 1970s and as shown in Figure 1, the first rising levels were spotted in the late 1990s to reach its highest record of $\$ 4.4$ billion in 2009 and close at $\$ 2.88$ billion in 2018 .

The aim of this paper is focused on identifying and analysing the effect of selected economic variables on FDI in Lebanon. This paper is organised as follows: Section 2 reflects some underlying theories and empirical studies consisting of the relationship between FDI and its main determinants throughout the world. Section 3 provides an empirical analysis detailing the used data, applied econometric methodology, estimated equations and results 
in order to explain the impact of the selected determinants on FDI inflow in Lebanon. The final section will provide overall conclusions and recommendations.

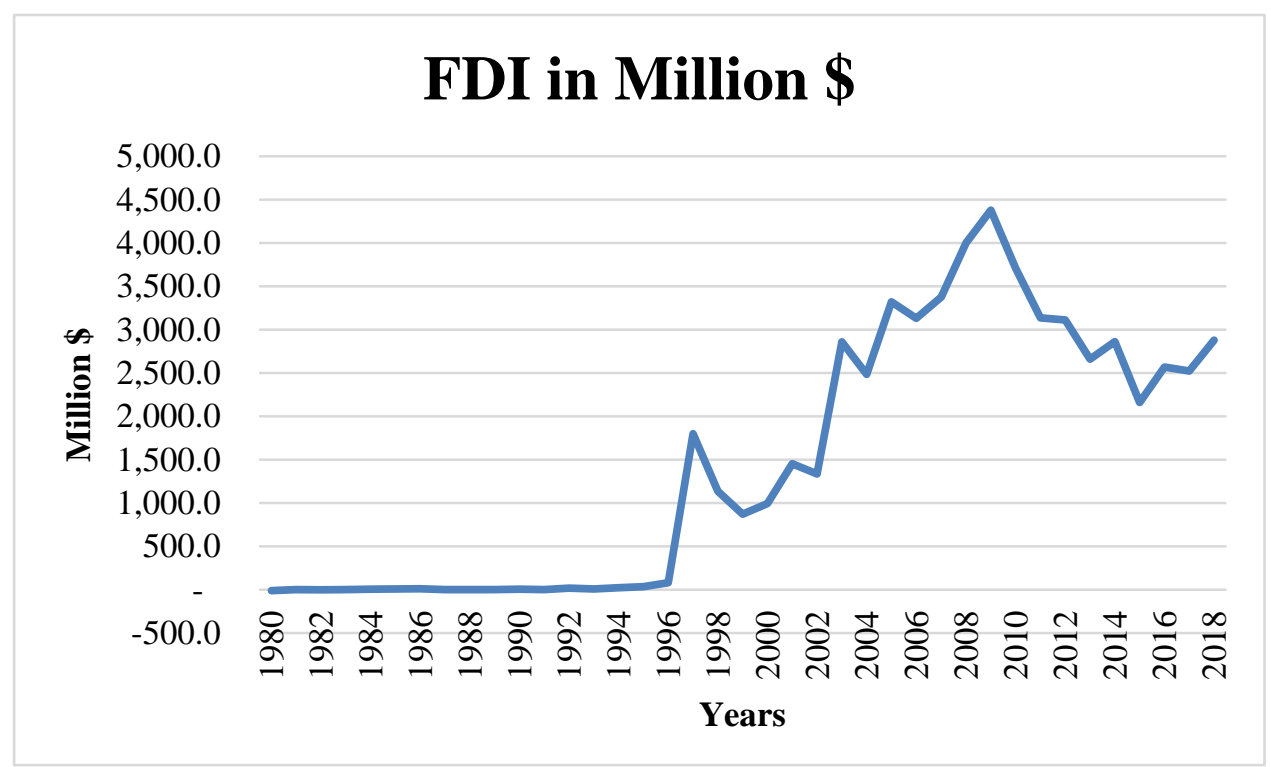

Source: The author

Figure 1. FDI inflows to Lebanon, 1980-2018

\section{Theoretical Background}

Several studies and theories have explained the level and patterns of FDI emphasizing different causal variables (Borensztein et al., 1998; Hermes \& Lensink, 2003).

Siddiqui and Aumeboonsuke (2014) have summarized number of determinants and their relationship with FDI differentiated below between positively and negatively proportional:

- Independent variables that have a positive effect on FDI are GDP growth rate, stable inflation rate, real interest rate, openness of economy, international reserves, political stability, infrastructure as roads and airports, natural resource availability, market size, stable exchange rate, trade surplus and money growth.

- Independent variables that are inversely proportional to FDI are labor cost trade barriers, external debt, taxes, and trade deficit.

The study done by Siddiqui and Aumenboonsuke (2014) on Thailand, Philippine and Indonesia for the years between 1986 and 2012 using Vector Auto Regression (VAR) technique have concluded that low real interest rates attract FDI inflow only in the case of Thailand, while GDP did not show any positive role in all countries. In addition, it was concluded that increase in FDI inflow will decrease both interest rates and inflation which implies price stability.

From their side, Hansen and Rand (2006) have analysed the causal relationship between FDI and GDP using a sample of 31 developing countries selected from Asia, Latin America and Africa. The results indicated a strong causal link from FDI to GDP.

According to Erdal and Tatoglu (2002), although Turkey offers various advantages to foreign investors, it was found out that the lack of both exchange rate and economic stability has slowed down the FDI pace. Using Johansen time series analysis, the FDI equation model was estimated to find out the influence of selected independent variables on FDI measured by actual inflows to Turkey. The effect of the causal variables on FDI found are as below:

- Size of domestic market was found to have a positive impact,

- Openness of the economy to foreign trade was found to have a positive impact,

- Infrastructure of the host country was found to have a positive impact,

- Attractiveness of the domestic market was found to have a positive effect,

- Exchange rate instability of domestic currency was found to have negative effect on FDI,

- Economic instability was found to have insignificant negative effect. 
Moving to Shirazi et al. (2008), a panel data analysis was done on fifteen MENA countries differentiating between Gulf Cooperation Council (GCC) and non-GCC countries. Applying the fixed effects model, the random effects models and the Hausman test, the study tried to explain the relationship between the dependent variable FDI and the explanatory variables that are manufacturing as a percentage of GDP, openness index, inflation and the share of service. The results were representative for the differed economic structures of MENA countries where some are rich in oil, others have abundant supply of labor and the rest is endowed in both natural resources and labor. From one side, service was found to be the only significant variable in GCC countries. On another side, both openness and manufacturing were found to be significant for non-GCC countries.

In the same context, Mohamed and Sidiropoulos (2010) have conducted fixed effects and random effects regression panel models in order to analyse the main determinants of foreign direct investment in twelve MENA countries. The study included internal factors such as GDP, macroeconomic policies as well as external factors for instance global liquidity and trade. The results revealed that the key determinants of FDI in the countries under study were size of the host economy, government size, natural resources and institutional variables.

Kral (2004) have conducted an empirical analysis based on quantitative data in order to describe the determinants of FDI in the case of the Czech economy. The paper examined the impact of different variables including GDP, current account deficit and government expenditure on FDI through cointegration analysis and Error-correction model. The results implied that macroeconomic stability and external equilibrium are critical for the attraction and growth of investments in the country. Using the same statistical tools, Tang et al. (2008) have applied a multivariate VAR system with error correction model in order to test the correlation existing between FDI, domestic investment and economic growth in China. It was found out that domestic investment and economic growth had a bi-directional causality while single-directional causality exist moving from FDI toward domestic investment and economic growth. In other words, FDI aroused not only capital shortage but also economic growth in China.

\section{Methodology}

This section is allocated for the presentation of the empirical results drawn from econometric estimations based on secondary data in order to determine the impact of four selected variables on FDI inflows in the case of Lebanon. The data related to Deposit Interest rate is retrieved from WorldBank data official website (World Development Indicators), while all other used variables are extracted from UNCTAD statistics.

\subsection{Description of the Data}
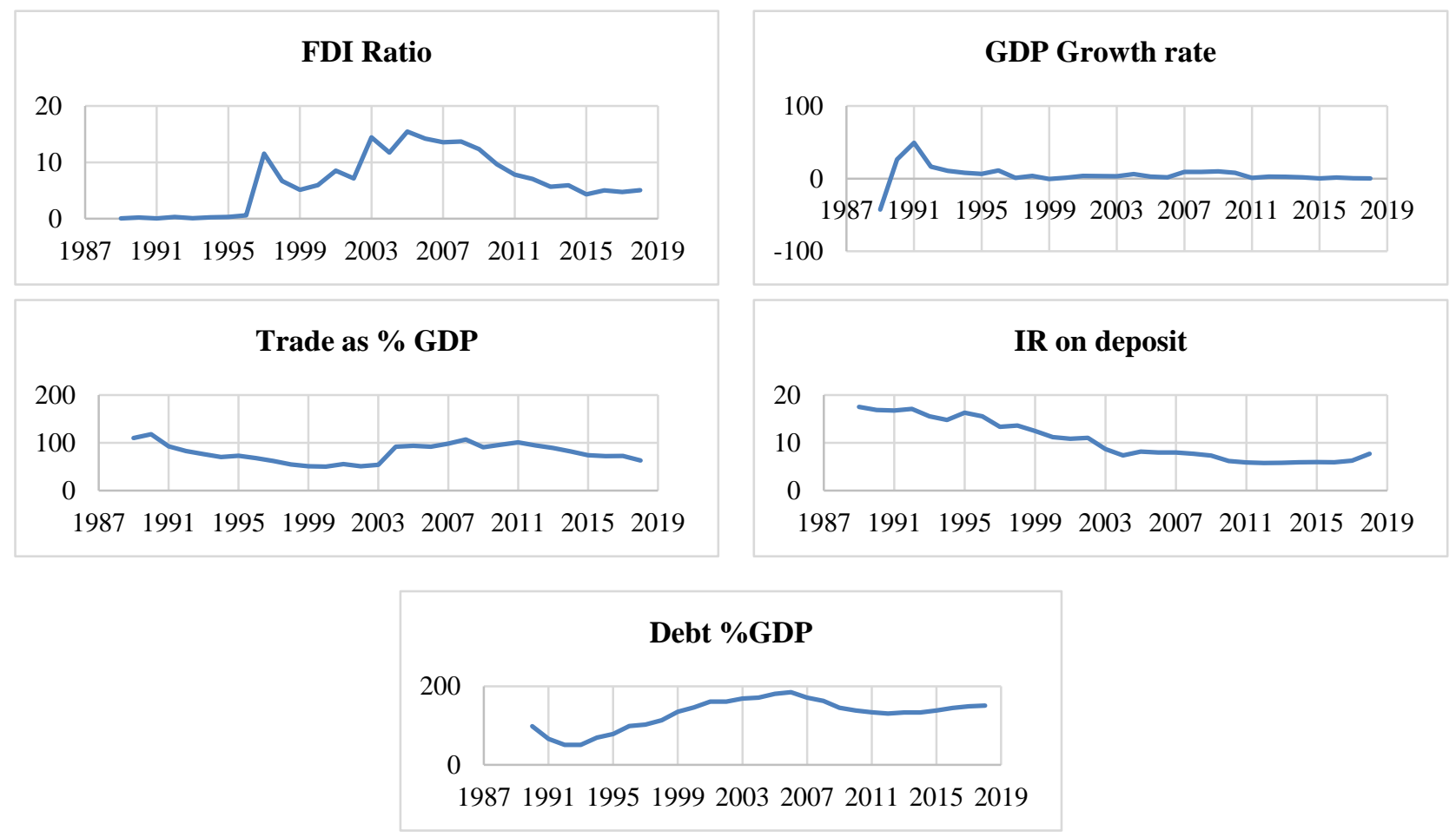

Source: The author

Figure 2. The Development of the FDI ratio and other Related Variable 
The annual development of FDI inflows will be the dependent variable. As previously mentioned in the theoretical background, there exists multiple factors affecting the movement of FDI. In our case, the impact on FDI will be examined depending on four variables. The observation period starts in 1989 and ends in 2018. Both years 2019 and 2020 were dropped from the study due to the special economic situation of the country and the impact of the COVID-19 pandemic. Figure 2 illustrates the movement of the FDI as percentage of GDP and other independent variables chosen in this study.

The independent variables employed in this study are as below:

- Attractiveness of the domestic market is represented by the growth rate of Gross Domestic Product (GDP) in percentage,

- Trade as a percentage of GDP is the measure of the openness of Lebanon to foreign trade,

- Debt as percentage of GDP and Interest rate on deposits reflects the overall economic instability.

\subsection{Augmented Dickey-Fuller (ADF) Unit Root Test}

The plotted figures above show that the series seem to be non-stationary in the level form. Time series is said to be stationary in the case when it repetitively returns to its mean and does not tend to drift (Asmy et al., 2009). The econometric methodology applied to analyse the conditions of stationary is the Augmented Dickey-Fuller test (ADF) at both level form and first difference with neither trend nor constant and lag length of six. The ADF test has developed the following null and alternative hypotheses (Tang et al., 2008).

- Null hypothesis: Ho: The series is non-stationary.

- Alternative Hypothesis: H1: The series is stationary.

The results of the ADF test are reported in Table 1 below. The null hypothesis of a unit root is rejected at level form I(0) for only IR and GDP Growth. Applying the first difference, the results indicate that all series are found to be stationary at order one.

Table 1. ADF test - Unit Root Summary

\begin{tabular}{ccccc}
\hline \multirow{2}{*}{ Series Variable } & \multicolumn{2}{c}{ Level Form } & \multicolumn{2}{c}{ 1st Difference } \\
\cline { 2 - 5 } & ADF Test Statistics & 5\% Critical Value & ADF Test Statistics & 5\% Critical Value \\
\hline FDI Inflow & -0.07 & -1.95 & -6.46 & -1.95 \\
IR & -2.43 & -1.95 & -4.10 & -1.95 \\
GDP Growth & -2.71 & -1.95 & -8.69 & -1.95 \\
Debt to GDP & 0.48 & -1.95 & -2.00 & -1.95 \\
Trade & -1.46 & -1.95 & -4.76 & -1.95 \\
\hline
\end{tabular}

\subsection{Johansen Cointegration Test}

Having concluded that each of the time series is stationary at $\mathrm{I}(1)$, the existence of a long-run equilibrium relationship shall be tested. This will be done using the Johansen Cointegration test that is applied where the null hypothesis of no cointegration is either accepted or rejected. The data used is as below:

$>$ DFDI - the first difference of FDI inflow.

$>$ IR - Deposit Interest rate at level form.

$>$ GDP_growth - GDP growth rate at level form.

$>$ DDebt - First difference of debt to GDP ratio.

$>$ DTrade - First difference of trade.

Table 2. Results of the Johansen Cointegration Test

\begin{tabular}{|c|c|c|c|c|}
\hline \multicolumn{5}{|c|}{ Series tested: DFDI, IR, GDP-GROWTH, DDEBT, DTRADE } \\
\hline \multicolumn{5}{|c|}{ Sample (adjusted) 1993 - 2018} \\
\hline Eigenvalue & Likelihood Ratio & 5\% Critical Value & $1 \%$ Critical Value & Hypothesized No. of CE(s) \\
\hline 0.838491 & 105.9918 & 69.81889 & 77.81884 & None $(*)(* *)$ \\
\hline 0.679574 & 60.41196 & 47.85613 & 54.68150 & At most $1(*)(* *)$ \\
\hline 0.477042 & 31.95934 & 29.79707 & 35.45817 & At most $2(*)$ \\
\hline 0.327176 & 15.75298 & 15.49471 & 19.93711 & At most $3(*)$ \\
\hline 0.208518 & 5.846194 & 3.841466 & 6.634897 & At most $4(*)$ \\
\hline
\end{tabular}

Note: $(*)$ and $(* *)$ denotes rejection of the hypothesis at $5 \%$ and $1 \%$ significance level respectively. 
Table 2 presents the results of the Johansen Cointegration test showing the Eigenvalues, likelihood ratios and critical values while Table 3 presents the Normalized Cointegration Vector.

The Johansen test results designate the existence of five statistically significant cointegrating vectors among the tested variables at the 5\% significance level while only two were identified at the $1 \%$ significance level. Consequently, we report the cointegrating coefficients in long-run equation form normalized on Foreign Direct Investment inflow (DFDI) as follows:

Table 3. The Normalized Cointegration Vector

\begin{tabular}{cccccc}
\hline Variable & DFDI & IR & GDP_Growth & Debt & Trade \\
\hline Normalized cointegrating coef. & 1 & -258.5775 & 169.0817 & 66.90903 & -69.71080 \\
Standard Error & & 54.8472 & 47.1230 & 22.0925 & 9.84827 \\
\hline
\end{tabular}

The results presented in Table 3 of the normalized cointegration vector indicates that all variables are statistically significant. In addition, both the deposit interest rate (IR) and the Trade have negative signs while GDP growth and debt presents positive signs.

\subsection{The Error Correction Model}

Having more than one cointegrating vector implies us to use the error correction model in order to analyse the causal relationship between FDI and each of the independent variables. The ECM is a restricted Vector Autoregression (VAR) mainly designed for cointegrated nonstationary time series.

\subsubsection{The Error-Correction Model}

Table 4. The Error Correction Model

\begin{tabular}{ccccc}
\hline $\begin{array}{l}\text { Dependent Variable: DFDI } \\
\text { Sample adjusted: 1994 2018 }\end{array}$ & & & \\
\hline Variable & Coefficient & Standard Error & T-Statistic & P-Value \\
\hline C & 332.5561 & 124.9922 & 2.660614 & 0.0196 \\
IR(-2) & 636.5142 & 140.0869 & 4.543711 & 0.0006 \\
GDP Growth (-1) & 130.8167 & 39.88231 & 3.280069 & 0.006 \\
Debt(-2) & 29.38785 & 13.36039 & 2.199626 & 0.0465 \\
Trade & -19.21920 & 15.23543 & -1.261481 & 0.2293 \\
R-Squared & 0.873936 & & F-Statistic & 8.192927 \\
Adjusted R-squared & 0.767266 & & Prob(F-statistic) & 0.000346 \\
\hline
\end{tabular}

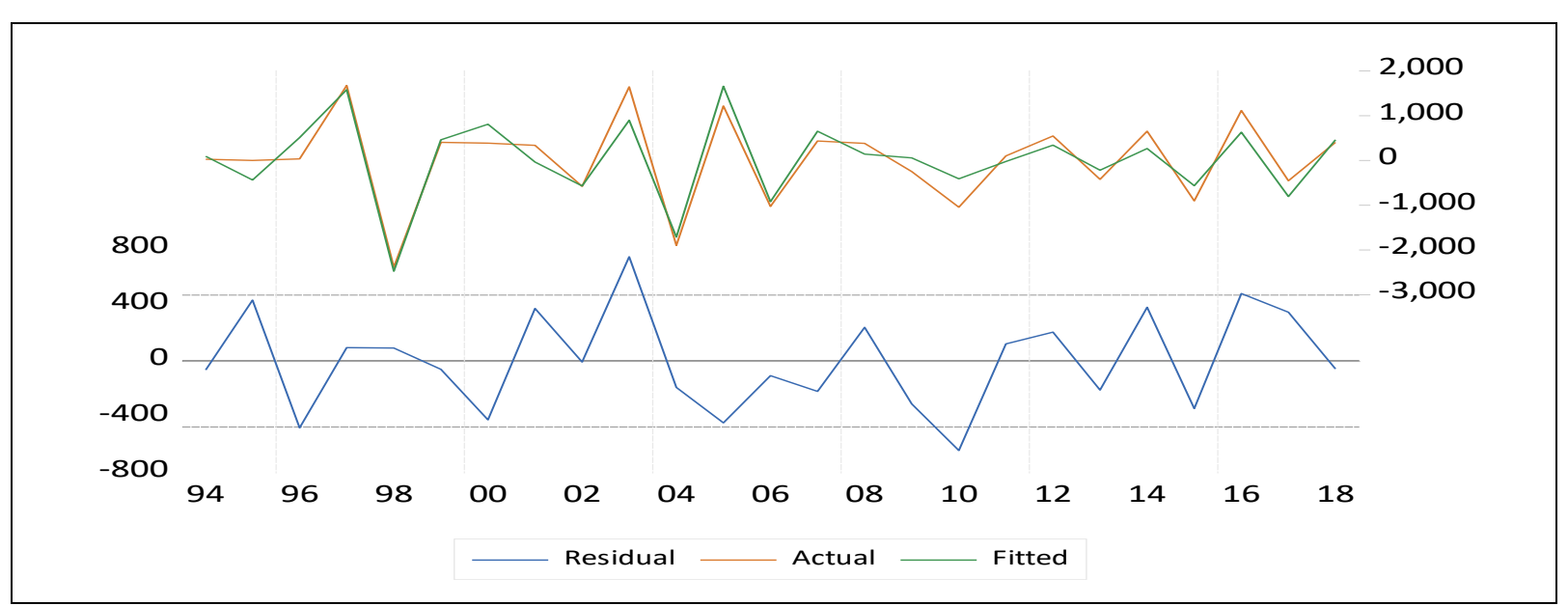

Figure 3. The In-Sample Fit of the Estimated Model

From the results drawn in Table 4, the below can be noted:

i. $\quad \mathrm{C}$ is a constant.

ii. The dependent variable is the first difference of FDI inflow.

iii. The error correction-term from the ECM model was found to be both negative and significant, then a long-run causality exists in the whole model moving from GDP growth, trade, debt, and interest rate on one 
side to FDI on another side.

iv. Lebanese GDP growth is positively correlated with FDI which means great economic growth spurs larger investments.

v. Interest rate was found to be positively related to FDI; higher deposit interest rates will encourage investments.

vi. Trade was not found to have significant impact on foreign direct investments in the long run.

vii. The R-squared of $87 \%$ and the probability of the F-statistic were found significant which means that the data is well prepared.

The in-sample fit of the above estimated model is shown in Figure 3.

\subsubsection{Wald Test- Coefficient Restrictions}

The Wald test or also called the Wald-Chi Squared test is used to test the significance of the explanatory variables used in a model. In our case, the Wald test is applied on each variable coefficient to reject or accept the null hypothesis of insignificance of the variable. Based on table 5 below, all variables used in the model are found to be significant, moreover, it can be concluded that there exists a short run causality running from each independent variable to FDI.

Table 5. Wald Test

\begin{tabular}{ccccc}
\hline Coefficient Variable & Test Statistic & Value & df & Probability \\
\hline IR-deposit & Chi-Square & 20.73003 & 2 & 0.0000 \\
GDP Growth & Chi-Square & 13.12177 & 2 & 0.0014 \\
DDebt & Chi-Square & 6.783825 & 2 & 0.0336 \\
Trade & Chi-Square & 9.532212 & 2 & 0.0085 \\
\hline
\end{tabular}

Rejection of null hypothesis at the $5 \%$ significance level.

\subsubsection{Residual Diagnostics}

\subsubsection{LM Test}

The Lagrange multiplier (LM) test statistic is used to detect any serial correlation among the variables. Table 6 shows that the null hypothesis cannot be rejected as the probability of Chi-Square exceeds the significance level of $5 \%$, then it can be concluded that no serial correlation exists among the variables.

Table 6. LM Test

Breusch-Godfrey Serial Correlation LM Test:

Null hypothesis: No serial correlation at up to 2 lags

\begin{tabular}{cccc}
\hline F-statistic & 0.633077 & Prob. F(2,11) & 0.5492 \\
\hline Obs*R-squared & 2.580585 & Prob. Chi-Square(2) & 0.2752 \\
\hline
\end{tabular}

\subsubsection{Heteroskedasticity Test}

This test is designed to detect any linear forms of heteroskedasticity which means that the standard errors of the variables are not monitored and non-constant over time. Table 7 accepts the null hypothesis of Homoskedasticity as the probability of Chi-Square is almost $99.97 \%$.

Table 7. Heteroskedasticity Test

\begin{tabular}{|c|c|c|c|}
\hline \multicolumn{4}{|c|}{ Heteroskedasticity Test: Breusch-Pagan-Godfrey } \\
\hline \multicolumn{4}{|c|}{ Null hypothesis: Homoskedasticity } \\
\hline F-statistic & 1.009406 & Prob. F(15,9) & 0.5139 \\
\hline Obs*R-squared & 15.67979 & Prob. Chi-Square(15) & 0.4036 \\
\hline Scaled explained SS & 2.818208 & Prob. Chi-Square(15) & 0.9997 \\
\hline
\end{tabular}

\subsubsection{Normality Test}

The normality graph plotted in Figure 4 shows that the residuals are normally distributed with a Jarque-Bera probability of $74.8 \%$. 


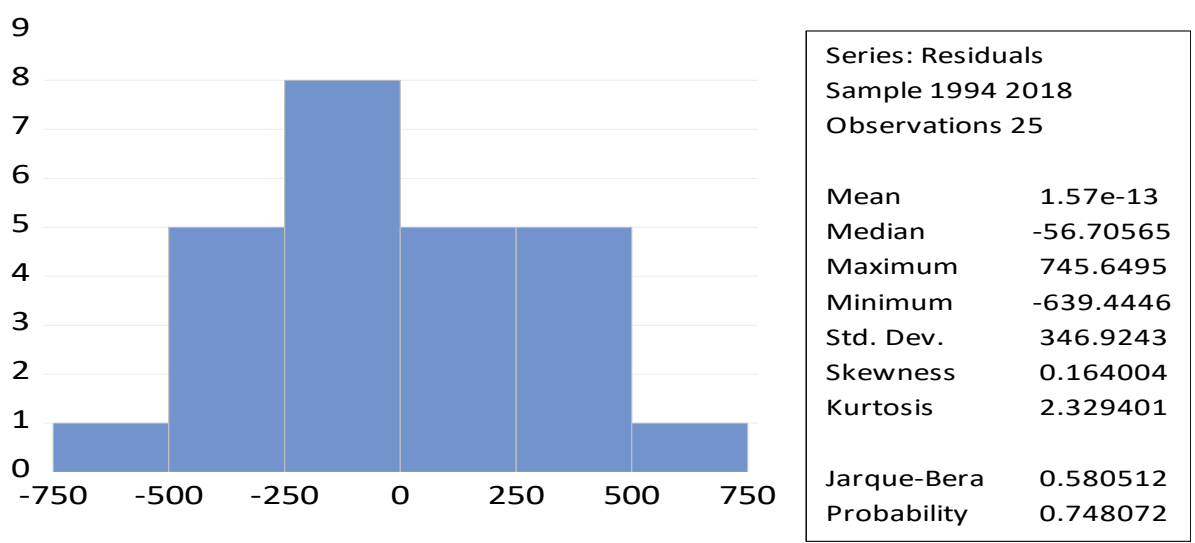

Figure 4. Normality test graph

\subsection{Summary and Interpretation of the Empirical Results}

In summary, we conclude that we have successfully proven statistically that long-run and short-run cointegrating relationship exist between FDI inflow from one side and the below macroeconomic factors from another side:

- Deposit interest rate, which is used as a measure of the country's openness,

- GDP growth rate as a measure of the attractiveness of the domestic market,

- Debt as a percentage of GDP reflecting the overall economic instability.

On another note, the results indicate that trade as a measure of the country's openness did not show significant causal link with FDI. The results drawn from applying different statistical tools on both coefficient and residuals implies that the data is well prepared, and all variables are significant. Based on the results of the error correction model, the government is suggested to stimulates the economic stability and the openness of its economy in order to accelerate the FDI pace.

\section{Conclusion}

The main goal of this paper is to acquire quantitative evidence in order to identify and analyse the causal relationship between foreign direct investment and different macroeconomic variables in Lebanon. By applying the Vector Auto Regression model and error correction model, the empirical results indicate that the growth rate of the Lebanese GDP, the deposit interest rate and the debt are all correlated with FDI inflow in Lebanon. Trade was found statistically uncorrelated with FDI. Hence, the results presented in this study can serve as a starting point for some policy recommendations.

Recently, Lebanon is facing a critical economic instability due to different socio-political factors such as corruption, outdated legislative regime and complex civilization measures. The government is recommended to operate some business restructuring in order to boost its financial and economic stability and by result attracting the foreign investors to have long-term interest in Lebanese enterprises.

\section{References}

Asmy, M., Rohilina, W., Hassama, A., \& Fouad, M. (2009). Effects of macroeconomic variables on stock prices in Malaysia: An approach of error correction model. Retrieved from https://mpra.ub.uni-muenchen.de/id/eprint/20970

Atala, I., Dagher, W., \& Chebib, N. (2016). Foreign Direct Investment in Lebanon. International journal of economy, management and social sciences, 5(3), 39-51. TI Journal, ISSN: 2306-7276

Borensztein, E., De Gregorio, J., \& Lee, J. W. (1998). How does foreign direct investment affect economic $\begin{array}{llll}\text { growth? Journal of international } & \text { Economics, }\end{array}$ https://doi.org/10.1016/S0022-1996(97)00033-0

Caccia, F. C., Baleix, J. M., \& Paniagua, J. (2018). FDI in the MENA Region: Factors that Hinder or Favour Investments in the Region. https://doi.org/10.1111/j.1467-9701.2006.00756.x

Erdal, F., \& Tatoglu, E. (2002). Locational determinants of foreign direct investment in an emerging market economy: Evidence from Turkey. Multinational business review, 10, 21-27, Emerald Publishing SSN: $1525-383 \mathrm{X}$ 
Hansen, H., \& Rand, J. (2006). On the causal links between FDI and growth in developing countries. World Economy, 29(1), 21-41. https://doi.org/10.1111/j.1467-9701.2006.00756.x

Hermes, N., \& Lensink, R. (2003). Foreign direct investment, financial development and economic growth. The journal of development studies, 4O(1), 142-163. https://doi.org/10.1080/00220380412331293707

Král, P. (2004). Identification and measurement of relationships concerning inflow of FDI: the case of the Czech Republic. Working Papers 2004/05, Czech National Bank. Retrieved from https://EconPapers.repec.org/RePEc:cnb:wpaper:2004/05

Mohamed, S. E., \& Sidiropoulos, M. G. (2010). Another look at the determinants of foreign direct investment in MENA countries: an empirical investigation. Journal of economic development, 35(2), 75. Retrieved from https://EconPapers.repec.org/RePEc:jed:journl:v:35:y:2010:i:2:p:75-95

Shirazi, A., Rodrigues, G., \& Karnik, A. (2008). Determinants of Foreign Direct Investment in MENA countries: an empirical analysis. First International Business Conference.

Siddiqui, H. A. A., \& Aumeboonsuke, V. (2014). Role of Interest Rate in attracting the FDI: Study on ASEAN 5 Economy. International Journal of Technical Research and Applications, 2(3), 59-70. Retrieved from http://repository.nida.ac.th/handle/662723737/4122

Tang, S., Selvanathan, E. A., \& Selvanathan, S. (2008). Foreign direct investment, domestic investment and economic growth in China: A time series analysis. World Economy, 31(10), 1292-1309. https://doi.org/10.1111/j.1467-9701.2008.01129.x

\section{Copyrights}

Copyright for this article is retained by the author(s), with first publication rights granted to the journal.

This is an open-access article distributed under the terms and conditions of the Creative Commons Attribution license (http://creativecommons.org/licenses/by/4.0/). 